\title{
sciendo
}

DOI 10.2478/sbe-2020-0019

SBE no. 15(1) 2020

\section{DOES EXCHANGE RATE HAVE ASYMMETRIC IMPACT ON TRADE BALANCE? FRESH INSIGHTS FROM COMBINED COINTEGRATION}

\author{
SOLOMON PRINCE NATHANIEL \\ University of Lagos, Akoka, Nigeria
}

\begin{abstract}
:
The study examines the asymmetric impact of exchange rate on the trade balance in Nigeria relying of time series data that spans 1960-2016. The Non-linear ARDL bounds test and the Bayer and Hanck (2013) test established a cointegrating relationship among the variables after accounting for structural break in the series. The Block Exogeneity Wald Tests affirmed the bidirectional causality between the variables. Findings establish the asymmetric impact of exchange rate on the trade balance in Nigeria, but unable to confirm the existence of the J-curve Phenomenon. This reveals that the devaluation of the Naira may not be a viable decision if the intention is to curb the persistent deficit in the country's trade balance. Policies that could help curtail these deficits and enhance sustainable growth were suggested.
\end{abstract}

Key words: Trade balance, Nonlinear ARDL, Exchange rate, Nigeria

\section{Introduction}

The rhetoric and empirics that surround the perceived relationship between trade balance and exchange rate have been well established in the literature. The literature is awash with studies that tried to explore the role played by exchange rate, in terms of its impact on the trade balance. Will exchange rate depreciation or appreciation improve or worsen a country's trade balances? Is an important question greeted with mixed results (Kyophilavong et al., 2018). A good understanding of the link between these variables can help policymakers initiate a viable monetary policy (Rehman \& Aftab, 2015). The stability of the exchange rate is sacrosanct. The advantages associated with this is hydra-headed, as it can help promote growth (Mrabet \& Alsamara 2018; Akinbobola \& Oyetayo 2010; Apollos 2015; Vieira \& MacDonald 2012), determine export (Adaramola 2016; Oyovwi 2012) and ensures a countries competitiveness. In spite of these advantages, the exchange rate in Nigeria has remained grossly unstable over the years. In 1981, for instance, it was $\$ 0.61$ to one US dollar. It slipped to $\$ 2.0206$ in 1986, $\$ 9.9095$ in 1991, 21.886 in 1996 , \#111.9433 in 2001, and it was $\$ 153.8616$ and $\$ 199.268$ in 2011 and 2015 respectively. The trade balance has not fared well as it keeps oscillating between positive and negative 
values. In 1981, the country witnessed a deficit of $-\$ 1.8$ billion. In 1986, it assumed a positive value of 2.9 billion. From 1991 to 1997, the country enjoyed a trade surplus, and this continued till 2014 with 1998 being the only exception. In 2015, however, the trade balance was in a deficit $(\$ 2,230.9)$ corresponding to $\$ 199.268$ exchange rate to a dollar. Findings have shown that a greater part of the surpluses the country witnessed was mainly driven by oil-export, not non-oil export. See Table1 below.

Table 1: Trend of trade balance, exchange rate, trade balance (with oil) and trade balance (without oil) in Nigeria

\begin{tabular}{lcccc}
\hline Year & Exchange rate & TB (with oil) & TB (without oil) & Total TB \\
\hline $2010 / 11$ & 152.3297 & $11,279.6$ & $-7,038.8$ & $4,240.8$ \\
$2011 / 12$ & 155.9402 & $11,195.7$ & $-5,823.0$ & $5,372.8$ \\
$2012 / 13$ & 155.7537 & $11,702.5$ & $-5,879.9$ & $5,822.6$ \\
$2013 / 14$ & 156.9828 & $9,791.9$ & $-7,370.2$ & $2,421.7$ \\
$2014 / 15$ & 199.268 & $6,459.3$ & $-8,690.2$ & $-2,230.9$ \\
$2015 / 16$ & 305.3421 & $5,436.2$ & -5726.3 & -290.1 \\
\hline
\end{tabular}

Note: TB represents trade balance. All figures are in billions of Naira.

Source: CBN Statistical Bulletin, 2016.

The negative values in the trade balance in 2015 and 2016 could be attributed to the recession the country witnessed during these periods. The country bounced back in 2017 to maintain a positive trade balance of 4,035 .5billion.

The principal reason behind exchange rate policy is to enhance its stability (Kyophilavong et al., 2018). As a result, in order to curtail the upward and downward swings in both variables, Nigeria has moved from one exchange rate policy/regime to the other. The fixed exchange rate regime was practised between 1960 and 1972 . There was a paradigm shift to the managed float system from 1973 to 1978 . The Dutch Auction System existed in 1987. This system did not yield the desired result giving room for the reintroduction of the pegged exchange rate system in 1994. Between 2006 and 2013 the country settled for the wholesale Dutch auction system having previously adopted the retail Dutch auction system. At present, the managed float system is being favoured against other alternatives. Previous studies in Nigeria arrived at a conflicting result. Some are in support of a positive impact (Ogbonna 2009, 2011; Igue \& Ogunleye 2014; Oladipupo 2011) while others discovered the opposite (Loto 2011; Omojimite \& Akpokodje 2010). Poor methodology could have contributed to the discrepancies in the results. To make up for this inadequacy, the present study employs the asymmetric ARDL approach (with the longest annual time series data in the literature) since most time series data are known to exhibit a non-linear trend. With this, the current study adds to the existing literature as the researcher is not aware of any study in Nigeria that has estimated the relationship between both variables (bivariate model) in a non-linear framework. Moreover, non-linear models are known to have greater explanatory power than linear models (Altintas \& Yacouba 2018; Meo et al. 2018). 
This study is organised as follows: Sec. 2. presents a brief literature review. Sec. 3. contains the data source and methodology. In Sec. 4. results are presented and discussed. Sec. 5. gives conclude and policy direction.

\section{Literature Review}

The three major theories that link both variables in literature are: Elasticity Approach also referred to as the Bickerdike-Robinson-Metzler Condition, postulates that the adjustment of trade balance is closely knitted with the elasticity of demand. Demand elasticities, export and import supply, and the initial trade volume are the core determinants of changes in the foreign currency value (Bickerdike, 1920). However, this approach had been further modified by Metzler (1945) and Robinson (1947). The Monetarist Approach assigned deficit in trade balance to an increase in money supply. This makes it a monetary phenomenon (Dunn \& Mutti, 2000). The Keynesian Absorption Approach was first modelled by Meade (1951) and Alexander (1952). This approach is the combination of Keynesian macroeconomics and the elasticities approach. There will be an improvement in trade account if domestic absorption is less than domestic output growth (Dunn \& Mutti, 2000). The phenomenon of the J-curve has gained more attention in the literature. Studies that have failed to establish its existence include (Wijeweera \& Dollery 2013; Kyophilavong et al. 2016; Shahbaz et al. 2012; Musawa 2014; Awan et al. 2012; Schaling \& Kabundi 2014; Oskooee \& Cheema 2009; Rahman et al. 2012; Shahbaz et al. 2010) while studies that confirm its existence include (Gupta-Kapoor \& Ramakrishnan 1999; Bahnmani-Oskooee \& Harvey 2010; Narayan 2004; Wijeweera \& Dollery 2013; Bahmani-Oskooee \& Kutan 2009; Bhmani-Oskooee \& Wang 2006)

Kyophilavong et al., (2018) confirmed the existence of no J-curve between Lao and Thailand. Economic growth in Lao deters its trade balance. On the flip side, a rise in Thailand's income is accompanied by trade balance improvement in Lao. Musawa (2014) examined a similar relationship for Zambia relying solely on the VECM approach. The impact of the exchange rate on the country's trade balance was only felt in the long run thereby failing to confirm the J-curve hypothesis for Zambia. With the same methodology, but with a different data span with that of Musawa (2014), Lucy et al. (2015) estimate a similar relationship for Ghana. Findings suggest that once the Ghana Cedes is depreciated, the trade balance of the country improves. The authors, however, call for the continuous depreciation of the Cedes in order to expunge deficit in the trade balance.

Šimáková (2014) used the VECM with data spanning 1997-2013 to investigate the J-curve hypothesis in aggregate and disaggregate framework. Instead, the study discovered an inverse $\mathrm{J}$-curve relationship. This suggests that depreciation improves the trade balance up to a certain threshold, after which it dwindles. Prakash \& Maiti (2016) incorporated political stability into the model in Fiji. The impact of exchange rate on trade balance was strong while that of political instability was not significant. Similar to the finding of Prakash \& Maiti (2016) with a similar methodology Buba et al. (2018) did not discover any significant effect of political instability on the trade balance in Thailand. For them, exchange impacts on trade balance because of the country's massive importation. 
Chiu \& Sun (2016) examined a similar relationship for seventy-six countries. They alluded importance to the savings rate. They discovered that a savings rate in excess of $14.8 \%$ can significantly induce the trade balance. Bahmani-Oskooee \& Fariditavana (2016) ascertained the J-curve existence for the US relying on asymmetric (NARDL) and nonasymmetric ARDL approach for six of its trading partners. The NARDL approach performed better than the former as findings support the phenomenon in five out of the six countries, as opposed to just two for linear ARDL.

Khan et al. (2016) relying on the ARDL approach, could not establish the existence of the J-curve relationship for Pakistan. They concluded that the devaluation of Pakistan currency will not be in favour of the country's trade balance. Hassan et al. (2017) used the ARDL approach with time series data spanning 1989Q1-2015Q4 to explore the same relationship in Nigeria. Findings support the significant impact of fiscal balance on the exchange rate. Jibrilla \& Mohammed (2015) provided evidence of the slow impact of exchange rate devaluation on trade balance from an asymmetric ECM modelling with monthly data for Nigeria. Their findings laid partially credence to the Dutch Disease phenomenon. They concluded that resulting in Naira devaluation as a tool for improving the trade balance will be a 'wild goose' chase. Rather, diversifying the economy is key.

\section{Data Source and Methodology}

The study used annual data spanning 1960-2016 from the Central Bank of Nigeria Statistical Bulletin (2017). The Non-linear ARDL model advanced by Shin et al. (2014) was used for analysis. The linear form of the model is given as:

$T B_{t}=\psi_{0}+\psi_{1} E X R_{t}+\varepsilon_{t}$

Where $T B_{t}, E X R_{t}$ and $\varepsilon_{t}$ are the trade balance, exchange rate and the error term respectively. All variables are in their log-linear form. Given the above specification, it would be difficult to capture the asymmetric impact of exchange rate on the trade balance. We can account for asymmetries by re-specifying Eq. 1 as:

$T B_{t}=\xi_{0}+\xi_{1} E X R_{t}^{+}+\xi_{2} E X R_{t}^{-}+\varepsilon_{t}$

The asymmetries in the variable are accounted for by introducing both the positive and negative values of the exchange rate in the equation. $E X R_{t}^{+}$and $E X R_{t}^{-}$.

$E X R_{t}^{+}=\sum_{i=1}^{t} \Delta E X R_{i}^{+}=\sum_{i=1}^{t} \max \left(\triangle E X R_{i}, 0\right)$

$E X R_{t}^{-}=\sum_{i=1}^{t} \Delta E X R_{i}^{-}=\sum_{i=1}^{t} \min \left(\triangle E X R_{i}, 0\right)$

From Eq.2., $\xi_{1}$ and $\xi_{2}$ capture the magnitude of both the positive and negative shocks of the exchange rate (in the long-run) on trade balance respectively. +To capture the short run effect, we can re-specify Eq.2 as:

$$
\begin{aligned}
& \Delta T B_{t}=\gamma_{0}+\gamma_{1} T B_{t-1}+\gamma_{2} E X R_{t-1}^{+}+\gamma_{3} E X R_{t-1}^{-}+\sum_{k=1}^{m} \omega_{k} \Delta T B_{t-k}+\sum_{k=1}^{m} \omega_{k} \Delta E X R_{t-k}^{+}+ \\
& \sum_{k=1}^{m} \omega_{k} \Delta E X R_{t-k}^{-} \\
& +\mu_{t}
\end{aligned}
$$

From Eq.5, the long run impact of both positive and negative changes in the exchange rate are

$\xi_{1}=-\gamma_{2} / \gamma_{1}$ and $\xi_{2}=-\gamma_{3} / \gamma_{1} \cdot \sum_{k=1}^{m} \omega_{k} \Delta E X R_{t-k}^{+}$and $\sum_{k=1}^{m} \omega_{k} \Delta E X R_{t-k}^{-}$are both the short run impact of positive and negative changes respectively. 


\section{Studies in Business and Economics no. 15(1)/2020}

\section{Presentation and Discussion of Results}

The study proceeds to examine the characteristic of each of the variables used in the study. The descriptive statistic of the variables along with the correlation matrices is shown in Table 4.1 below.

Table 4.1: Descriptive Statistic of Variables

\begin{tabular}{lcc}
\hline Variables & TB & EXR \\
\hline Mean & 5.8303 & 1.9364 \\
Median & 6.1650 & 1.5122 \\
Minimum & 0.6469 & -0.6044 \\
Maximum & 8.6695 & 5.7214 \\
Skewness & -0.5100 & 0.2459 \\
Kurtosis & 2.2219 & 2.3719 \\
Jarque-Bera & 3.0178 & 7.2012 \\
Probability & 0.2211 & 0.0273 \\
TBL & 1.0000 & \\
EXR & $(0.430)^{\star * *}$ & 1.0000 \\
& &
\end{tabular}

Results show that the mean of each of the variables almost equals their median values. The trade balance is positively skewed while the exchange rate is negatively skewed. Both variables are platykurtic and positively correlated. Their probability values confirm the normality of trade balance, not the exchange rate.

As a precautionary motive to avoid spurious regression, the study proceeds with the Augmented Dickey Fuller (ADF), Philips and Perron (PP), Kwiatkowski-PhillipsSchmidt-Shin KPSS (1992) stationarity tests and the Zivot and Andrew (ZA) (1992) unit root to account for a structural break in the series.

Table 4.2a: ADF and PP unit root tests (without break)

\begin{tabular}{lccc}
\hline Variables & ADF & PP & KPSS \\
\hline TBL & $-3.264039(1)^{* *}$ & $-3.264039(1)^{* *}$ & 0.393567 \\
EXR & $0.633842(1)$ & $0.367652(1)$ & 0.844688 \\
$\Delta$ TBL & $-7.840120(1)^{\star}$ & $-8.411754(1)^{*}$ & 0.108854 \\
$\Delta$ EXR & $-5.714509(1)^{*}$ & $-5.765492(1)^{*}$ & 0.266622 \\
\hline
\end{tabular}

** and * indicate significance at $5 \%$ and $1 \%$ respectively.

Table 4.2b: Zivot-Andrews Unit root test

\begin{tabular}{lllll}
\hline Variables & \multicolumn{2}{c}{ At levels } & \multicolumn{2}{c}{ At First Difference } \\
\hline & \multicolumn{1}{c}{ T-Stat. } & Time Break & T-Stat. & Time Break \\
\hline TBL & $-3.369916(2)^{\star *}$ & {$[2004]$} & $-5.541456(2)^{\star *}$ & {$[2002]$} \\
EXR & $-0.515989(1)$ & {$[1999]$} & $-3.833020(1)^{\star *}$ & {$[1997]$} \\
\hline
\end{tabular}

Note: ( ) shows lag length of the variables. ${ }^{* *}$ show significance at $5 \%$. 
The four tests are in harmony. While trade balance is significant at levels, exchange rate became significant only after first difference. It should be noted that the ADF and PP tests have a null hypothesis of unit root, while the KPSS test has a reverse null hypothesis of no unit root. Since the ARDL approach perform better in the presence of mixed level of stationarity we can therefore proceed with the ARDL bounds test. See Table 4.3.

Table 4.3: NARDL Bounds Test Results

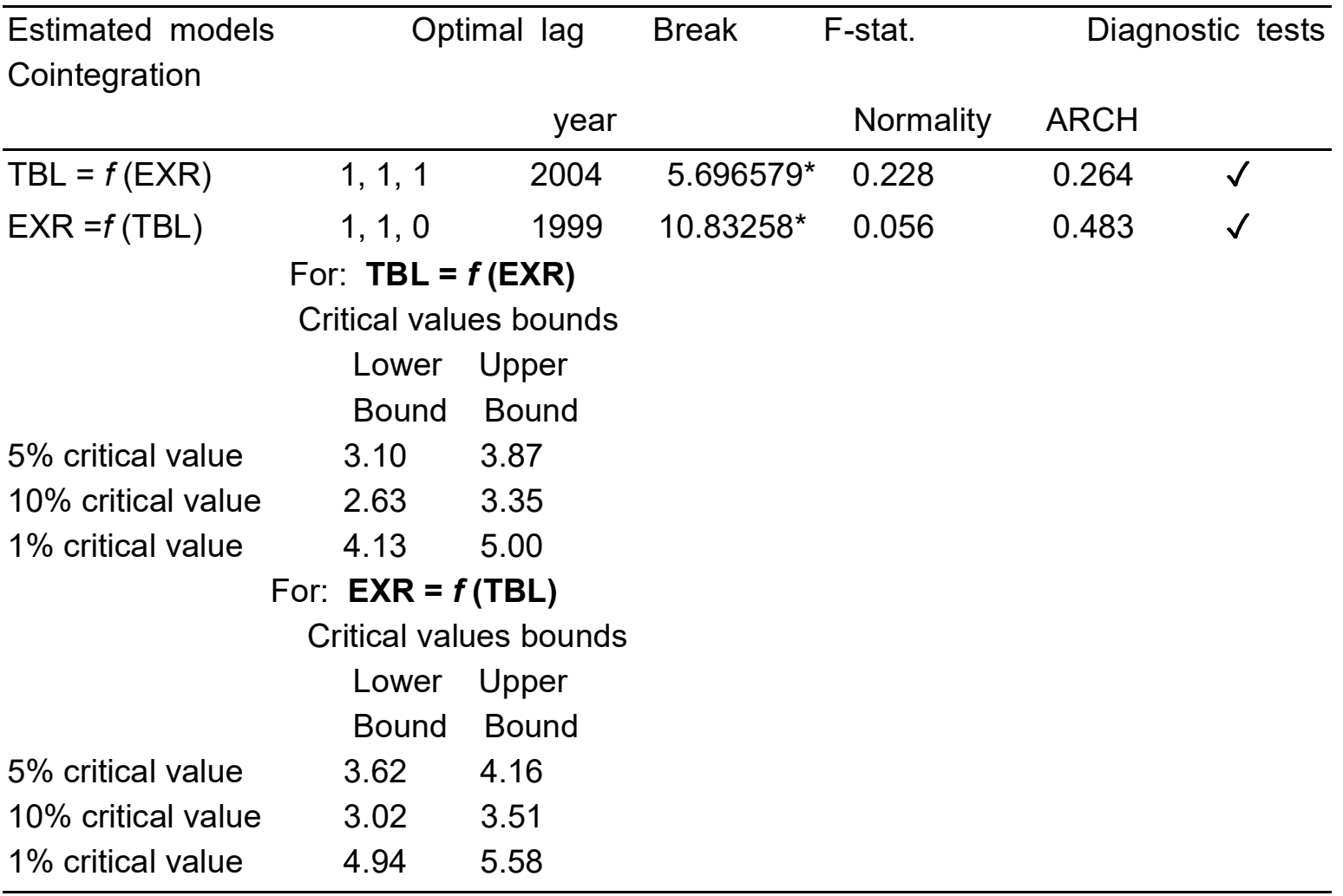
Note: ${ }^{*}$ indicate significance at $1 \%$ level.

The results from the bounds tests above affirm the presence of cointegrating relationship between the variables as the F-statistic of the variables is greater than the $5 \%$ significance level of the upper bound. To complement the NARDL bounds test, the study also relied on the Bayer and Hanck (2013) combined cointegration test. The test is a combination of other individual tests like (Johansen 1991; Boswijk 1995; Engle \& Granger 1987; Banerjee et al.,1998). The Fisher equation for the test are shown in Eq. (6) and (7) below;

$$
\begin{aligned}
& E G-J O H=-2\left[\ln \left(\rho_{E G}\right)+\left(\rho_{I O H}\right)\right] \\
& E G-J O H-B O-B D M=-2\left[\ln \left(\left(\rho_{E G}\right)+\left(\rho_{I O H}\right)+\left(\rho_{B O}\right)+\left(\rho_{B D M}\right)\right]\right.
\end{aligned}
$$

$\rho_{B D M}, \rho_{B O}, \rho_{I O H}$ and $\rho_{E G}$ are the test probability of individual cointegration tests.

Table 4.4: Bayer-Hanck test for Cointegration

\begin{tabular}{lccc}
\hline Estimated models & EG-JOH & EG-JOH-BO-BDM & Cointegration \\
\hline $\mathrm{TBL}=\mathrm{f}(\mathrm{EXR})$ & $11.524^{* *}$ & $22.278^{* *}$ & Yes \\
$\mathrm{EXR}=\mathrm{f}(\mathrm{TBL})$ & $13.431^{* *}$ & $23.267^{* *}$ & Yes \\
$5 \%$ critical value & 11.229 & 21.931 & \\
\hline
\end{tabular}

Note: ${ }^{* *}$ indicate significance at $5 \%$ levels. 
The Fisher statistic are greater than the 5\% critical values of 11.229 and 21.931 respectively, we can safely conclude that the variables (TBL and EXR) are cointegrated.

Table 4.5: ARDL Short-run and Long-run Analysis

\begin{tabular}{|c|c|c|c|c|c|}
\hline \multicolumn{6}{|c|}{ Dependent Variable: TBL } \\
\hline Variables & \multirow{2}{*}{\multicolumn{2}{|c|}{$\begin{array}{l}\text { Coefficients } \\
0.090500\end{array}$}} & Std. Error & t-Statistic & Prob. \\
\hline C & & & 0.044413 & 2.037685 & 0.0465 \\
\hline D(EXR_POS) & \multicolumn{2}{|c|}{-0.655371} & 0.151043 & -4.338959 & 0.0001 \\
\hline D(EXR_NEG) & \multicolumn{2}{|c|}{-9.202277} & 5.508661 & -1.670511 & 0.1012 \\
\hline TBL(-1) & \multicolumn{2}{|c|}{-0.776268} & 0.135842 & -5.714509 & 0.0000 \\
\hline EXR_POS & \multicolumn{2}{|c|}{-0.603417} & 0.129678 & -4.653184 & 0.0000 \\
\hline EXR_NEG & \multicolumn{2}{|c|}{-0.00400} & 0.28000 & -0.014285 & 0.0002 \\
\hline $\mathrm{Eq}(-1)$ & \multicolumn{2}{|c|}{-0.655371} & 0.133274 & -4.917458 & 0.0000 \\
\hline $\mathrm{R}^{2}$ & \multicolumn{3}{|c|}{0.52453} & & \\
\hline D-W Stat & \multicolumn{3}{|c|}{1.83793} & & \\
\hline \multicolumn{2}{|c|}{$\begin{array}{c}\text { Diagnostic Checks } \\
\text { Test }\end{array}$} & \multicolumn{2}{|c|}{ F-statistic } & & \\
\hline \multicolumn{2}{|l|}{$X^{2} \mathrm{ARCH}$} & \multicolumn{2}{|l|}{0.5678} & & \\
\hline \multicolumn{2}{|c|}{$X^{2}$ Serial correlation } & \multicolumn{2}{|l|}{0.2343} & & \\
\hline \multicolumn{2}{|l|}{$X^{2}$ Normality } & \multicolumn{2}{|l|}{0.1432} & & \\
\hline
\end{tabular}

From Table 4.5 above, the lag value (first lag) of trade balance exacts a significant impact on its current value. A $1 \%$ increase corresponds to about $77 \%$ decrease in the trade balance. In the short run, a positive shock in the exchange rate will lead to about $65 \%$ decrease in the country's trade balance holding the effects of other variables constant. The same impact, but of different magnitude is associated with a negative shock. However, the impact of a negative shock is not significant. As a negative shock is accompanied with about $9.2 \%$ decrease in the trade balance. The magnitude of the impact between positive shocks in the short run differs from that of the long run. In the long run, a positive shock in the exchange rate will lead to $60 \%$ decrease in trade balance. The impact of a negative shock, in the long run, is consistent with that of the long run. Both are insignificant and their impacts are negative. An interesting discovery from the finding is that the exchange rate has an asymmetric impact on the country's trade balance. This is intuitive. More so, the negative impact of a positive shock of the exchange rate in both time periods negates the existence of the J-curve phenomenon for Nigeria. This is in line with the findings of Wijeweera \& Dollery (2013), Kyophilavong et al. (2016), Shahbaz et al. (2012), Musawa (2014), Kyophilavong et al., (2018) and Jibrilla \& Mohammed (2015) for Nigeria. Suffice to say that, devaluation of the Naira may not be the solution to the persistent deficit in the country's trade balance. It is a tip-off to the relevant authority to incorporate viable policies that will enhance efficient proper exchange rate management which will in turn impact positively on its trade balance. The inability of the country to record a surplus in its trade balance has made it difficult for the proposed West Africa Monetary Zone (WAMZ) to properly take off, as this happens to be one of the criteria for its formation. The error correction term conforms to economic theory with a significant $t$ - 
statistic and a negative coefficient. The study is also in line with the various OLS assumptions.

Table 4.6: Block Exogeneity Wald Tests

\begin{tabular}{lccl}
\hline Dependent Variable: TBL & Chi-sq & df & Prob. \\
\hline EXR & 7.311138 & 2 & 0.0258 \\
All & 7.311138 & 2 & 0.0258 \\
\hline TBL & 13.53815 & 2 & 0.0258 \\
All & 13.53815 & 2 & 0.0258 \\
\hline
\end{tabular}

This test was used to confirm the direction of causality between the variables since impact does not necessarily mean causation. The test suggests the existence of a bidirectional causality between the variables.
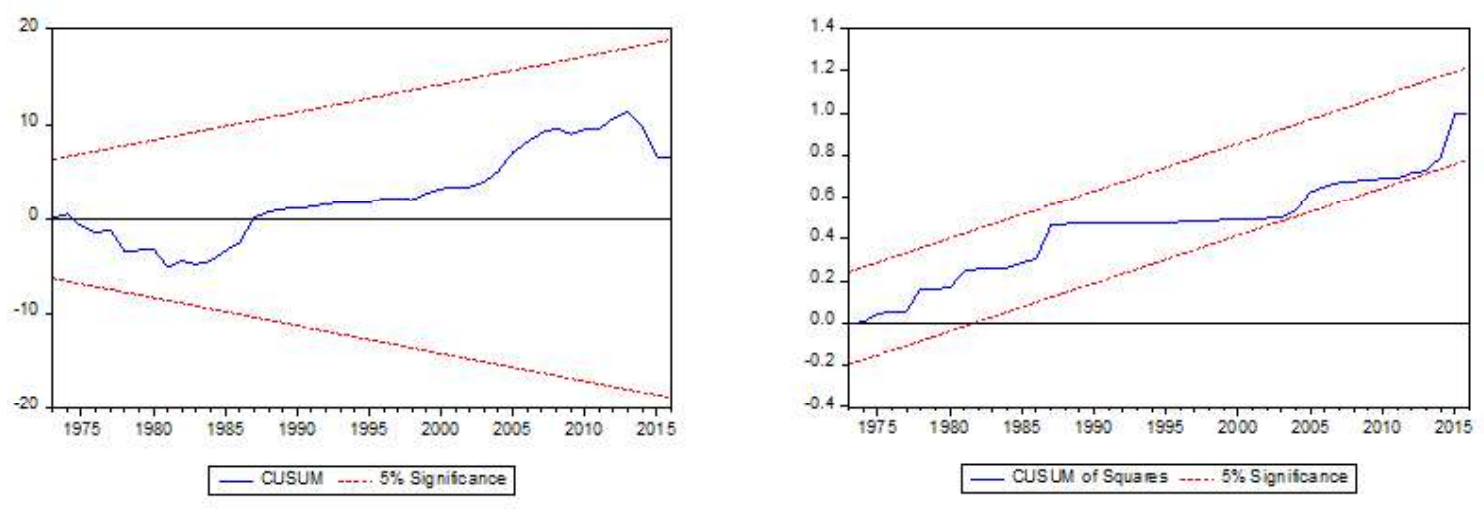

Figure 1: CUSUM and CUSUM (sq) Graph

The CUSUM and CUSUM (sq) Graph of Brown et al. (1975) confirm the stability of the model with the residuals within $5 \%$ critical bond. Therefore, the study can be a useful tool for forecasting and policy implementation.

\section{Conclusion and Policy Direction}

The study examines the asymmetric impact of exchange rate on the trade balance in Nigeria with time series data for the period 1960-2016. The Non-linear ARDL bounds test of Shin et al., (2014) the Bayer and Hanck (2013) test established a cointegrating relationship among the variables after accounting for a structural break in the series. The Block Exogeneity Wald Tests confirmed the bidirectional causality between both variables. Positive and negative shocks in exchange rate were associated with a negative impact on the country's trade balance, but only the positive shocks were significant. This confirmed the asymmetric impact of exchange rate on trade balance. To improve the country's trade balance, attention should be shifted to exportation, but not totally on primary products. There is also a dire need to minimize importation, especially on commodities that can be 
produced locally. Since the country currently has the largest population in Africa, meeting domestic need may prove difficult. However, providing adequate infrastructure and creating an enabling economic and political environment to help business thrive could be the game changer.

\section{References}

Adaramola, A. (2016) The Effect of Real Exchange Rate Volatility On Export Volume in Nigeria. FUTA Journal of Management and Technology, 1(2).

Akinbobola, T. O., \& Oyetayo, O. J. (2010). Econometric analysis of real exchange rate and domestic output growth in Nigeria. International Journal of Academic Research, 2(5).

Alexander, S. S. (1952). Effects of a Devaluation on a Trade Balance. Staff Papers, 2(2), 263-278.

Altintas, H., \& Yacouba, K. (2018). Asymmetric Responses of Stock Prices to Money Supply and Oil Prices Shocks in Turkey: New Evidence from a Nonlinear ARDL Approach. International Journal of Economics and Financial Issues, 8(4), 45.

Apollos, E. A., Emmanuel, A., \& Olusegun, D. J. (2015). Exchange rate volatility and economic growth in Nigeria. Journal of Empirical Economics, 4(2), 109-115.

Bahmani-Oskooee, M., \& Fariditavana, H. (2016). Nonlinear ARDL approach and the J-curve phenomenon. Open Economies Review, 27(1), 51-70.

Bahmani-Oskooee, M., \& Harvey (2010). The J-curve: Malaysia versus her major trading partners. Applied Economics, 42(9), 1067-1076.

Boswijk, H. P. (1995). Efficient inference on cointegration parameters in structural error correction models. Journal of Econometrics, 69(1), 133-158.

Engle, R. F., \& Granger, C. W. (1987). Co-integration and error correction: representation, estimation, and testing. Econometrica: Journal of the Econometric Society, 251-276.

Johansen, S. (1991). Estimation and hypothesis testing of cointegration vectors in Gaussian vector autoregressive models. Econometrica, 59(6), 1551-1580.

Bayer, C., \& Hanck, C. (2013). Combining non-cointegration tests. Journal of Time Series Analysis, 34(1), 83-95.

Banerjee, A., Dolado, J., \& Mestre, R. (1998). Error-correction mechanism tests for cointegration in a single-equation framework. Journal of time series analysis, 19(3), 267-283.

Bahmani-Oskooee, M., \& Kutan, A. (2009). The J-curve in the emerging economies of Eastern Europe. Applied Economics, 41(20), 2523-2532.

Bahmani-Oskooee, M., \& Wang, Y. (2006). The J-curve: China versus her trading partners. Bulletin of Economic Research, 58(4), 323-343.

Bickerdike, C. F. (1920). The instability of foreign exchange. The Economic Journal, 30(117), 118122.

Brown, R. L., J. Durbin and Evans, J. (1975). Techniques for testing the constancy of regression relationships over time. Journal of the Royal Statistical Society. Series B (Methodological), 149-192.

Buba, S., Garba, S. M. I. A. J., \& Guza, M. (2018). Asymmetric Co-integration between Exchange Rate and Trade Balance in Thailand. World, 4(1), 075-084.

Chiu, Y. B., \& Sun, C. H. D. (2016). The role of savings rate in exchange rate and trade imbalance nexus: Cross-countries evidence. Economic Modelling, 52, 1017-1025.

Dunn, R . \& Mutti, J (2000) International Economics, Routledge, London, United Kingdom, $5^{\text {th }}$ edition.

Gupta-Kapoor, A., \& Ramakrishnan, U. (1999). Is there a J-curve? A new estimation for Japan. International Economic Journal, 13(4), 71-79.

Hassan, A., Abubakar, M. I., \& Dantama, Y. U. (2017). Determinants of Exchange Rate Volatility: New Estimates from Nigeria. Eastern Journal of Economics and Finance, 3(1), 1-12. 
Igue, N. N., \& Ogunleye, T. S. (2014). Impact of real exchange rate on trade balance in Nigeria. African Development Review, 26(2), 347-358.

Jibrilla Aliyu, A., \& Mohammed Tijjani, S. (2015). Asymmetric cointegration between exchange rate and trade balance in Nigeria. Cogent Economics \& Finance, 3(1), 1045213.

Khan, Z., Ali, A., \& Ali, S. (2016). Impact of devaluation on balance of trade: A case study of Pakistan economy. Asian Journal of Economic Modelling, 4(2), 90-94.

Kyophilavong, P., Shahbaz, M., \& Uddin, G.S. (2016). Financial development and growth in Laos: Evidence from ARDL approach. Global Business Review, 17(2), 303-317.

Kyophilavong, P., Shahbaz, M., Rehman, I. U., Souksavath, S., \& Chanthasene, S. (2018). Investigating the Relationship between Trade Balance and the Exchange Rate: The Case of Laos' Trade with Thailand. Global Business Review, 19(3), 590-603.

Loto, M. A. (2011). Does devaluation improve the trade balance of Nigeria? (A test of the MarshallLerner condition). Journal of Economics and International Finance, 3(11), 624-633.

Lucy, A., Sunday, R. J., \& Pacific, Y. K. T. (2015). Exchange rate and trade balance in Ghana-testing the validity of the Marshall Lerner condition. International Journal of Development and Emerging Economics, 3(2), 38-52.

Meade, J. E. (1951). The removal of trade barriers: the regional versus the universal approach. Economica, 18(70), 184-198.

Meo, M. S., Chowdhury, M. A. F., Shaikh, G. M., Ali, M., \& Masood Sheikh, S. (2018). Asymmetric impact of oil prices, exchange rate, and inflation on tourism demand in Pakistan: new evidence from nonlinear ARDL. Asia Pacific Journal of Tourism Research, 23(4), 408-422.

Metzler, L. A. (1945). Stability of multiple markets: the Hicks conditions. Econometrica: Journal of the Econometric Society, 277-292.

Mrabet, Z., \& Alsamara, M. (2018). The impact of parallel market exchange rate volatility and oil exports on real GDP in Syria: Evidence from the ARDL approach. The Journal of International Trade \& Economic Development, 27(3), 333-349.

Musawa, N. (2014). Relationship between Zambias Exchange Rates and the Trade Balance-J Curve Hypothesis. International Journal of Finance and Accounting, 3(3), 192-196.

Ogbonna, B. C. (2009). Long Run Exchange Rate Effects on Trade Balance: Evidence from Nigeria, Journal of Research in National Development, 7(1), 127-36.

Ogbonna, B. C. (2011). The Impact of Exchange Rate Variations on Trade Balance: Evidence from Nigeria, Journal of Research in National Development, 9(2b), 393-403.

Oladipupo, A. O. (2011), 'Impact of Exchange Rate on Balance of Payment in Nigeria', African Research Review, 5(4), 73-88.

Omojimite, B. U., \& Akpokodje, G. (2010). The impact of exchange rate reforms on trade performance in Nigeria. Journal of social sciences, 23(1), 53-62.

Oskooee, B. and J. Cheema, (2009). Short-run and long-run effects of currency depreciation on the bilateral trade balance between Pakistan and her major trading partners. Journal of Economic Development, 34(1): 19-45.

Oyovwi, O. D. (2012). Exchange rate volatility and imports in Nigeria. Academic journal of Interdisciplinary Studies, 1(2), 103-114.

Prakash, K., \& Maiti, D. (2016). Does devaluation improve trade balance in small island economies? The case of Fiji. Economic Modelling, 55, 382-393.

Rahman, A., H.A. Iftikhar and A. Hafsa, (2012). Exchange rate, J-curve and debt burden of Pakistan. Pakistan Economic and Social Review, 50(1): 41-56

Rehman, I, U., and Aftab, M. (2015). On the Linkages between Exchange Rate, Inflation and Interest Rate in Malaysia: Evidence from Autoregressive Distributed Lag Modelling. Pakistan Journal of Statistics, 31(5).

Robinson, J. (1947). Essays in the Theory of Employment, Basil Blackwell, Oxford, United Kingdom. 
Schaling, E., \& Kabundi, A. (2014). The exchange rate, the trade balance and the J-curve effect in South Africa. South African Journal of Economic and Management Sciences, 17(5), 601-608.

Shahbaz, M., A. Jalil and F. Islam (2010). Real exchange rate changes and trade balance in Pakistan: A revisit. Munich Personal RePEc Archive (MPRA) Working Paper \# 27631.

Shahbaz, M., Jalil, A., \& Islam, F. (2012). Real exchange rate changes and the trade balance: The evidence from Pakistan. The International Trade Journal, 26(2), 139-153.

Shin, Y., Yu, B., \& Greenwood-Nimmo, M. (2014). Modelling asymmetric cointegration and dynamic multipliers in a nonlinear ARDL framework. In Festschrift in Honor of Peter Schmidt (pp. 281314). Springer, New York, NY.

Šimáková, J. (2014). The effects of exchange rate change on the trade balance of Slovakia. European Financial and Accounting Journal, 9(3), 50-66.

Vieira, F. V., \& MacDonald, R. (2012). A panel data investigation of real exchange rate misalignment and growth. Estudos Econômicos (São Paulo), 42(3), 433-456.

Wijeweera, A., \& Dollery, B. (2013). J-curve disparity between the goods sector and the services sector: Evidence from Australia. Applied Economics Letters, 20(5), 452-456.

Zivot, E., \& Andrews, D. W. K. (1992).Further evidence on the Great Crash, the oil price shock, and the unit root hypothesis. Journal of Business and Economic Statistics, 10(3), 251-270. 